\title{
Peningkatan Pengetahuan Masyarakat Tentang Cuci Tangan Terkait Pandemi Covid-19 di Wilayah Kerja Puskesmas Kuranji Padang
}

\author{
Yuanita Ananda', Nelwati' ${ }^{1}$, Zifriyanthi Minanda Putri' ${ }^{1}$, Muthmainnah1', dan Edo \\ Gusdiansyah ${ }^{2}$ \\ 1Fakultas Keperawatan, Universitas Andalas, Kampus Limau Manis, Padang, 25163. Indonesia \\ ${ }^{2}$ STIKes Alifah Padang. Jl. Khatib Sulaiman No 52B Kelurahan Belanti, Padang, 25136. Indonesia \\ E-mail: yuanitaananda@nrs.unand.ac.id
}

Keywords:

Covid-19, hand washing, knowledge, society

\begin{abstract}
Entering the new normal era, people have started to carry out economic and social activities as usual. Even now the community is not afraid to be in a crowd without wearing a mask and not following the health protocol that has been socialized by the government. It is known that the number of new cases of patients infected with Covid19 every day is increasing with the most cases being in the city of Padang. One area that experienced an increase in the Covid case rate in the city of Padang was in the working area of the Kuranji Padang Health Center, in the Korong Gadang Village. The increase in these cases is due to lack of knowledge and awareness of the community against Covid-19 transmission and also the limitations of health workers in providing education to the community also become obstacles in the midst of this pandemic. Therefore, it is highly necessary to provide more in-depth education to people in the working area of the Kuranji Padang Health Center. Education was done online by giving a google form link to the public so that the pre-test and post-test scores are known and a booklet is given and this activity was carried out on July 7-8, 2020. The evaluation results showed that there is an increase in public knowledge about washing hands based on post-test. The activity would be monitored by the Health Center for the continuous education.
\end{abstract}

\begin{abstract}
ABSTRAK
Memasuki era new normal, masyarakat sudah mulai melakukan aktivitas ekonomi dan sosial seperti biasanya. Bahkan saat sekarang masyarakat sudah tidak takut berada ditempat keramaian tanpa menggunakan masker dan tidak mengikuti protokol kesehatan yang telah disosialisasikan oleh pemerintah. Diketahui bahwa angka kasus baru pasien terinfeksi Covid-19 setiap hari semakin meningkat dengan kasus terbanyak berada di kota Padang. Salah satu daerah yang mengalami peningkatan angka kasus Covid-19 di kota Padang yaitu di wilayah kerja Puskesmas Kuranji Padang yaitu di Kelurahan Korong Gadang. Peningkatan kasus tersebut disebabkan kurangnya pengetahuan dan kewaspadaan masyarakat terhadap penularan Covid-19 dan juga keterbatasan tenaga kesehatan dalam memberikan edukasi kepada masyarakat juga menjadi kendala di tengah pandemi ini. Oleh karena itu, sangat diperlukan sekali metode untuk pemberian edukasi yang lebih mendalam kepada masyarakat yang berada di wilayah kerja Puskesmas Kuranji Padang. Pelaksanaannya metode edukasi dilakukan secara online yaitu memberikan link google form kepada masyarakat sehingga diketahui nilai pre-test dan post-test serta
\end{abstract}


diberikan booklet dan kegiatan ini dilakukan pada tanggal 7-8 Juli 2020. Hasil evaluasi menunjukkan bahwa terjadi peningkatan pengetahuan masyarakat tentang cuci tangan pada post-test. Saran untuk pihak puskesmas yaitu melakukan monitoring terhadap keberlanjutan edukasi ini.

\section{PENDAHULUAN}

Coronavirus adalah zoonosis atau virus yang ditularkan antara hewan dan manusia. Virus dan penyakit ini diketahui berawal di kota Wuhan, Cina sejak Desember 2019. Per tanggal 25 April 2020, jumlah kasus penyakit ini mencapai angka 2,79 juta jiwa yang tersebar di 166 negara, termasuk Indonesia. Coronavirus-19 (COVID) telah dinyatakan sebagai pandemi dunia oleh WHO (WHO, 2020). Berdasarakan data WHO (2020), sebaran Covid-19 secara global terkonfirmasi sebanyak 7.941.791 kasus dengan angka kematian di dunia sebanyak 434.794 kasus. Indonesia menempati urutan ke-31 kasus sebaran Covid-19 secara global dari 216 negara, yang sudah terpapar Covid-19 dengan sebanyak 41.431 kasus terkonfirmasi positif dengan angka kematian 2.276 kasus. Provinsi Sumatera Barat menempati urutan ke-15 kasus sebaran Covid-19 dari seluruh Provinsi yang yang terpapar Covid-19 di Indonesia yaitu sebanyak 691 kasus terkonfirmasi positif dengan sebanyak 30 kasus meninggal dunia (Kemenkes RI, 2020).

Covid-19 pertama dilaporkan di Indonesia pada tanggal 2 Maret 2020 sejumlah dua kasus. Data 27 April 2020 menunjukkan kasus yang terkonfirmasi berjumlah 9.906 kasus dan 765 kasus kematian. Tingkat mortalitas Covid-19 di Indonesia sebesar 8,9\%, angka ini merupakan yang tertinggi di Asia Tenggara. Berdasarkan data pemantauan Covid-19 Dinkes Kota Padang tahun (2020), Kota Padang merupakan penyumbang kasus penyebaran Covid-19 terbanyak di Provinsi Sumatera Barat dengan angka kejadian kasus terkonfirmasi positif sebanyak 492 kasus, dengan kasus terbanyak berada di Kelurahan Kuranji yaitu sebanyak 44 kasus terkonfirmasi positif (Dinkes Kota Padang, 2020).

Presiden Republik Indonesia telah menyatakan status penyakit ini menjadi tahap Tanggap Darurat pada tanggal 17 Maret 2020. Presiden juga telah mengeluarkan Keputusan Presiden No. 7 Tahun 2020 tentang Gugus Tugas Percepatan Penanganan Corona yang diketuai oleh Kepala Badan Nasional Penanggulangan Bencana (BNPB). Gugus Tugas ini bertujuan untuk meningkatkan ketahanan nasional di bidang kesehatan, mempercepat penanganan Covid-19 melalui sinergi antar kementerian/lembaga dan pemerintah daerah, meningkatkan antisipasi perkembangan eskalasi penyebaran Covid-19, meningkatkan sinergi pengambilan kebijakan operasional, dan meningkatkan kesiapan dan kemampuan dalam mencegah, mendeteksi, dan merespons terhadap Covid-19.

Menghadapi wabah Covid-19 yang semakin hari semakin membuat takut dan menimbulkan rasa tidak aman bagi masyarakat dunia bahkan sampai ke Indonesia. Covid-19 adalah penyakit menular yang disebabkan oleh sindrom pernapasan akut coronavirus 2 (SARS-CoV-2) dengan gejala demam, batuk, sesak nafas, nyeri otot, diare, sakit tenggorokan dan sakit perut. Seringkali virus ini menyebar antara manusia ke manusia melalui tetesan cairan dari mulut dan hidung saat orang yang terinfeksi sedang batuk atau bersin, mirip dengan cara penularan penyakit flu. Tetes cairan dari mulut dan hidung pasien tersebut bisa jatuh dan tertinggal pada mulut dan hidung orang lain yang berada di dekatnya, bahkan dihisap dan terserap ke dalam paru-paru orang tersebut melalui hidungnya (Cigna, 2020).

Hingga saat ini belum ditemukan vaksin untuk mencegah seseorang terinfeksi virus Corona ini. Cara terbaik untuk melindungi diri adalah dengan menghindari kondisi atau tempat dimana berpotensi terpapar virus tersebut. Hal-hal ini untuk mencegah penyebaran penyakit tersebut yaitu: perbanyak cuci tangan menggunakan air, sabun dan pembersih tangan dengan kandungan 
alkokol paling banyak 60\% paling tidak selama 20 detik, terutama sebelum keluar kamar mandi, sebelum makan dan setelah buang ingus, atau batuk, atau bersin, hindari menyentuh wajah sebelum anda cuci tangan, hindari kontak dekat dengan orang-orang sakit, tinggal di rumah jika sakit, tutupi mulut saat batuk dan bersin dengan menggunakan tisu, perbanyak membersihkan barang-barang serta perabotan di rumah, serta menggunakan masker.

Selain itu, pemberian edukasi yang lebih mendalam kepada masyarakat harus dilakukan guna untuk memutus rantai penularan virus Covid-19 serta berguna untuk meningkatkan pengetahuan masyarakat tentang cuci tangan yang merupakan salah satu upaya pencegahan Covid-19. Masyarakat yang berada di wilayah kerja Puskesmas Kuranji Padang merupakan zona merah karena di wilayah tersebut terdapat peningkatan angka kejadian Covid-19. Peningkatan kasus tersebut disebabkan kurangnya pengetahuan dan kewaspadaan masyarakat terhadap penularan Covid-19 dan juga keterbatasan tenaga kesehatan dalam memberikan edukasi kepada masyarakat juga menjadi kendala di tengah pandemi ini. Oleh karena itu, sangat diperlukan sekali metode untuk pemberian edukasi yang lebih mendalam kepada masyarakat yang berada di wilayah kerja Puskesmas Kuranji Padang. Pelaksanaannya metode edukasi dilakukan secara online yaitu memberikan link google form kepada masyarakat sehingga diketahui nilai pre-test dan post-test. Tujuan dari tindakan ini yaitu meningkatkan pengetahuan masyarakat tentang cuci tangan yang merupakan salah satu upaya pencegahan Covid-19.

Edukasi dilakukan di wilayah kerja Puskesmas Kuranji Padang tepatnya di Kelurahan Korong Gadang Padang Provinsi Sumatera Barat. Masyarakat di wilayah tersebut beraneka ragam mulai dari keadaan sosial ekonomi menengah ke bawah sampai keadaan sosial ekonomi menengah ke atas. Himbauan dari pemerintah untuk melakukan work from home dan melakukan physical distancing tidak terlalu dihiraukan oleh masyarakat. Hal ini terlihat dari banyaknya masyarakat yang masih suka berkumpul-kumpul di tempat keramaian dan tidak mengikuti protokol kesehatan yang telah disosialisasikan oleh pemerintah padahal di wilayah tersebut sudah termasuk zona merah. Oleh sebab itu, edukasi sangat dibutuhkan di wilayah tersebut agar tidak terjadi peningkatan angka kasus Covid-19 dan memutus rantai penularannya.

\section{METODE}

Kegiatan edukasi ini dilakukan selama dua hari yang dimulai pada tanggal 7-8 Juli 2020. Edukasi dilakukan secara online melalui link google form yang diberikan kepada masyarakat dengan jumlah 40 orang. Metode pelaksanaan kegiatan yang dilakukan yaitu sebagai berikut:

1. Melakukan kerja sama dengan pihak Puskesmas Kuranji Padang untuk mengidentifikasi masyarakat yang terkena dampak Covid-19 di wilayah kerja Puskesmas Kuranji Padang khususnya di kelurahan Korong Gadang Padang.

2. Menyiapkan link google form yang akan diberikan kepada masyarakat dengan isi pertanyaan yang ringkas, jelas dan mudah dipahami oleh masyarakat. Serta menyiapkan booklet yang berisi materi tentang Covid-19, upaya pencegahan Covid-19, serta materi cuci tangan yang dapat diaplikasikan dalam kehidupan sehari-hari.

3. Penyuluh memberikan link google form untuk yang pertama kali yaitu untuk menilai pre-test masyarakat yang berguna untuk mengetahui pengetahuan awal masyarakat tentang Covid-19, upaya pencegahan, serta tentang metode cuci tangan.

4. Kemudian penyuluh memberikan edukasi terkait materi dengan menerapkan physical distancing dan protokol kesehatan. Pemberian materi dengan menggunakan media booklet yang diberikan kepada masyarakat.

5. Penyuluh melakukan demonstrasi cara penggunaan masker dan melakukan cuci tangan dengan tepat. 
6. Kemudian penyuluh memberikan link google form untuk yang kedua kalinya yaitu untuk menilai post-test. Dari hasil test tersebut dapat diketahui peningkatan pengetahuan masyarakat terkait materi yang telah disampaikan.

\section{HASIL DAN PEMBAHASAN}

Kegiatan edukasi dilaksanakan di Wilayah Kerja Puskesmas Kuranji Padang khususnya di Kelurahan Korong Gadang pada tanggal 7-8 Juli 2020. Kegiatan dilakukan kepada 40 orang masyarakat. Tim dosen yang melakukan edukasi yaitu Ns. Yuanita Ananda, M.Kep, Nelwati, S.Kp, MN, PhD, Ns. Zifriyanthi Minanda Putri, M.Kep dan Ns. Muthmainnah, M.Kep, Ns. Edo Gusdiansyah, M.Kep serta dibantu oleh dua orang mahasiswa. Edukasi yang dilakukan dengan media online yaitu menggunakan link google form yang diberikan kepada masyarakat dengan tetap memperhatikan protokol kesehatan dan melakukan physical distancing. Metode ini dipilih karena menghindari kerumunan dan tetap menjaga physical distancing. Adapun karakteristik masyarakat yang mengikuti kegiatan ini adalah sebagai berikut:

Tabel 1. Karakteristik masyarakat yang mengikuti program edukasi

\begin{tabular}{lcc}
\hline \multicolumn{1}{c|}{ Karakteristik } & Frekuensi & Persentase (\%) \\
\hline Jenis kelamin & & \\
Laki-laki & 18 & 45 \\
Perempuan & 22 & 55 \\
\hline Pendidikan Terakhir & & \\
- S2 & 2 & 5 \\
- S1 & 6 & 15 \\
- SMA & 28 & 70 \\
- SMP & 4 & 10 \\
\hline Agama & & \\
- Islam & 40 & 100 \\
& & \\
\hline Pekerjaan & & 10 \\
- PNS & 4 & 42.5 \\
- IRT & 17 & 47.5 \\
- Swasta & 19 & \\
\hline
\end{tabular}

Dari tabel diatas dapat dilihat bahwa sebagian besar masyarakat yang mengikuti program edukasi adalah perempuan (55\%), mayoritas pendidikan terakhir yaitu SMA (70\%), seluruhnya beragama Islam (100\%) dan pekerjaan Swasta (47,5\%) disusul dengan IRT (42,5\%).

Peningkatan pengetahuan dinilai secara kuantitatif. Adapun hasil dari evaluasi pemahaman peserta edukasi digambarkan pada tabel 2. Hasil test di tabel 2 dan gambar 1 menjelaskan bahwa terjadi perubahan yang signifikan tentang pengetahuan masyarakat sebelum dan sesudah dilakukan edukasi. Edukasi yang dilakukan secara langsung dan dari rumah ke rumah terbukti efektif untuk meningkatkan pengetahuan masyarakat. Namun, kekurangan teknik ini adalah membutuhkan waktu yang panjang dan tenaga yang tidak sedikit. 
Tabel 2. Gambaran peningkatan pengetahuan sebelum dan sesudah dilakukan edukasi

\begin{tabular}{|c|c|c|c|c|}
\hline \multirow[t]{2}{*}{$\begin{array}{c}\text { Komponen } \\
\text { Evaluasi }\end{array}$} & \multicolumn{2}{|c|}{$\begin{array}{l}\text { Pre test } \\
\text { n (\%) }\end{array}$} & \multicolumn{2}{|c|}{$\begin{array}{l}\text { Post test } \\
\text { n }(\%)\end{array}$} \\
\hline & Benar & Salah & Benar & Salah \\
\hline $\begin{array}{l}\text { Cara yang paling } \\
\text { efektif dan efisien } \\
\text { untuk mencegah } \\
\text { penularan infeksi } \\
\text { Covid-19 adalah }\end{array}$ & $10(25 \%)$ & $30(75 \%)$ & 40 (100\%) & 0 \\
\hline $\begin{array}{l}\text { Apa perlengkapan } \\
\text { saat melakukan cuci } \\
\text { tangan }\end{array}$ & $7(17,5 \%)$ & $33(82,5 \%)$ & $40(100 \%)$ & 0 \\
\hline $\begin{array}{l}\text { Apa yang dimaksud } \\
\text { dengan cuci tangan }\end{array}$ & $12(30 \%)$ & $28(70 \%)$ & 40 (100\%) & 0 \\
\hline $\begin{array}{l}\text { Apakah tujuan } \\
\text { dilakukannya } \\
\text { mencuci tangan }\end{array}$ & $9(22,5 \%)$ & $31(77,5 \%)$ & $40(100 \%)$ & 0 \\
\hline $\begin{array}{l}\text { Berapa langkah } \\
\text { yang efektif dalam } \\
\text { melakukan cuci } \\
\text { tangan }\end{array}$ & $5(12,5 \%)$ & $35(87,5 \%)$ & 40 (100\%) & 0 \\
\hline $\begin{array}{l}\text { Berapa kali } \\
\text { efektifnya kita } \\
\text { melakukan cuci } \\
\text { tangan }\end{array}$ & $8(20 \%)$ & $32(80 \%)$ & $40(100 \%)$ & 0 \\
\hline $\begin{array}{l}\text { Apakah bahan yang } \\
\text { dipakai sebagai } \\
\text { penganti mencuci } \\
\text { tangan dengan } \\
\text { sabun }\end{array}$ & $10(25 \%)$ & $30(75 \%)$ & 40 (100\%) & 0 \\
\hline $\begin{array}{l}\text { Sabun apa yang } \\
\text { paling cocok } \\
\text { digunakan untuk } \\
\text { mencuci tangan }\end{array}$ & $9(22,5 \%)$ & $31(77,5 \%)$ & $40(100 \%)$ & 0 \\
\hline $\begin{array}{l}\text { Berapakah } \\
\text { kandungan alcohol } \\
\text { yang terdapat dalam } \\
\text { Hand Sanitizier }\end{array}$ & $8(20 \%)$ & $32(80 \%)$ & 40 (100\%) & 0 \\
\hline $\begin{array}{l}\text { Berapa lama waktu } \\
\text { yang dibutuhkan } \\
\text { untuk melakukan } \\
\text { cuci tangan dengan } \\
\text { menggunakan sabun } \\
\text { dan air mengalir }\end{array}$ & $7(17,5 \%)$ & $33(82,5 \%)$ & $40(100 \%)$ & 0 \\
\hline
\end{tabular}




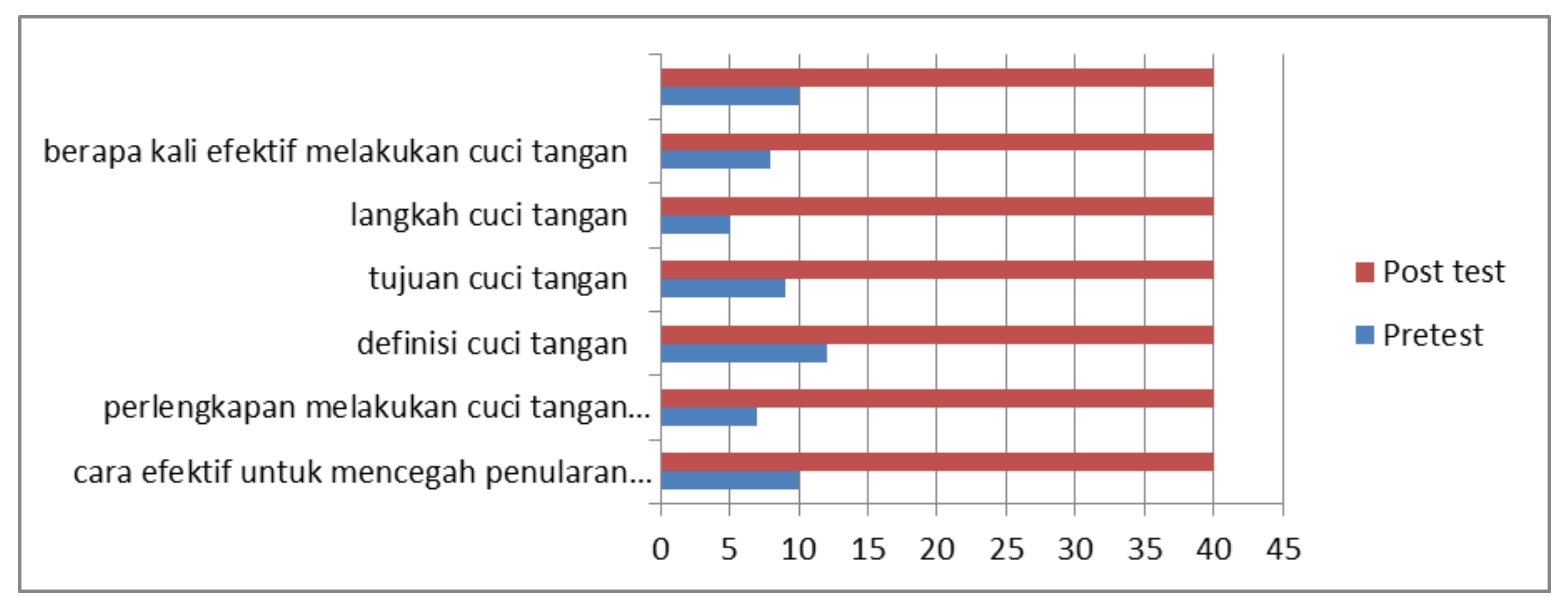

Gambar 1. Perbedaan tingkat pengetahuan pre dan post-test dilakukan edukasi

Pelaksanaan kegiatan edukasi ini dilakukan secara online yaitu menggunakan link google form yang diberikan kepada masyarakat. Form tersebut terdiri dari 10 pertanyaan dengan menggunakan bahasa yang ringan, mudah dimengerti dan dipahami oleh masyarakat. Setiap masyarakat mengisi form online tersebut sebanyak dua kali yaitu untuk menilai pre-test dan post-test. Sebelum masyarakat mengisi form untuk post-test, masyarakat diberikan edukasi melalui booklet yang berisi materi yang mudah dipahami dan diajarkan melakukan demonstrasi pemakaian masker dan melakukan cuci tangan. Secara umum, pelaksanaan kegiatan edukasi ini berjalan dengan lancar berkat kerjasama tim penyuluh, masyarakat, pihak Puskesmas Kuranji Padang yang telah memfasilitasi kegiatan ini.

Kendala yang dihadapi oleh tim penyuluh pada saat kegiatan yaitu ada beberapa masyarakat yang kurang paham bagaimana cara mengisi link online tersebut. Kendala tersebut bisa ditangani oleh tim penyuluh dengan memberikan penjelasan cara mengisinya. Dampak dari kegiatan ini sangat terasa dan bermanfaat bagi masyarakat, hal ini terlihat dari perbedaan tingkat pengetahuan masyarakat pada saat pre-test dan post-test serta masyarakat sudah bisa melakukan demonstrasi pemakaian masker dan cuci tangan. Hal ini dapat memutus rantai penularan virus Covid-19 di wilayah tersebut.

Upaya keberlanjutan kegiatan hasil pengabdian masyarakat ini yaitu dengan melakukan kontrol yang akan dilakukan bersama-sama dengan pihak Puskesmas Kuranji Padang guna memutus rantai penularan virus Covid-19. Dengan adanya kerjasama dari berbagai pihak, kita semua dapat membantu pemerintah dalam menanggulangi dan memutus rantai penularan Covid-19. Di akhir kegiatan edukasi ini, tim membagikan faceshild, hand sanitizier dan booklet edukasi kepada masyarakat. Hal ini dapat berguna bagi masyarakat dan dapat diaplikasikan dalam kehidupan sehari-hari. 


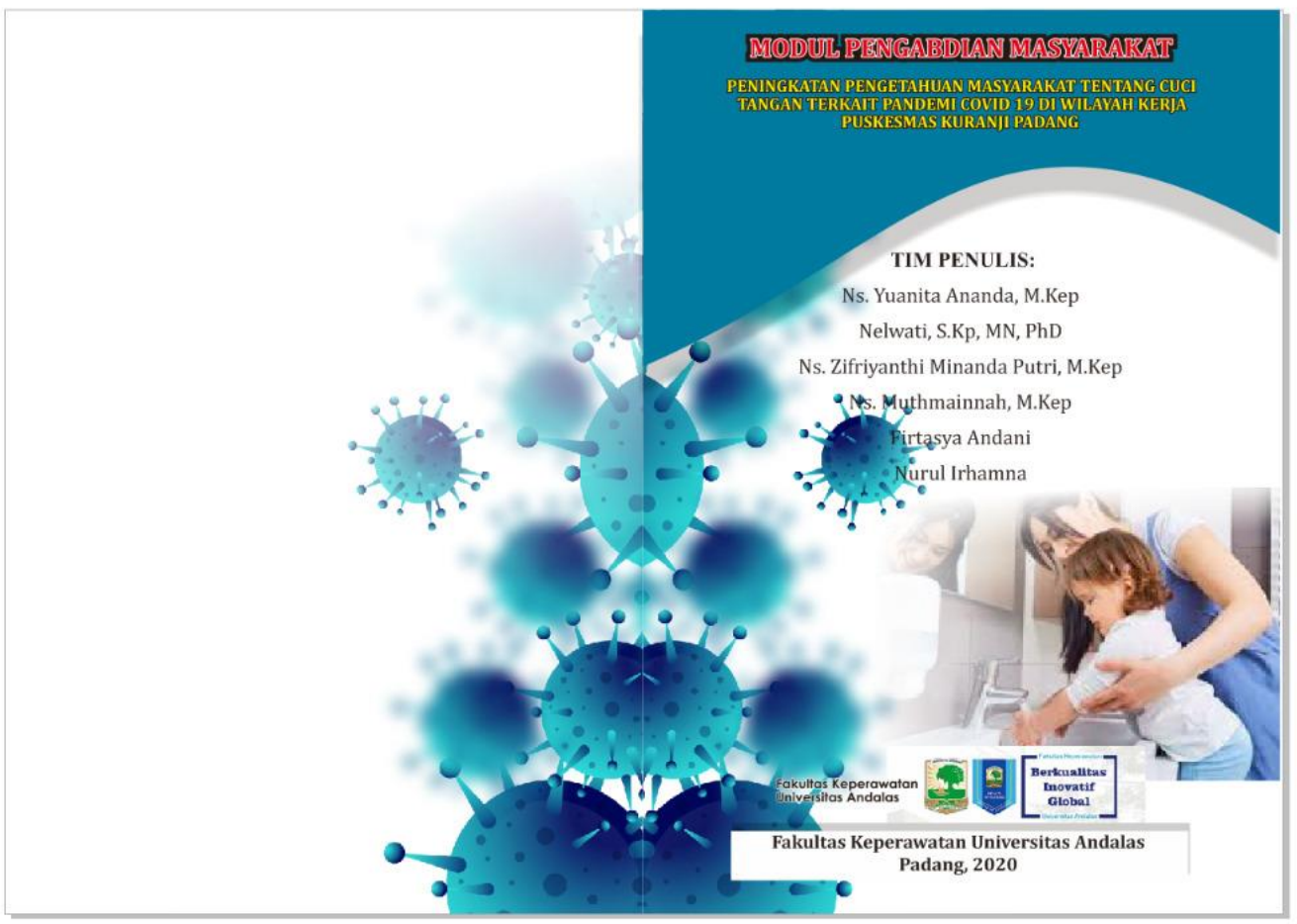

Gambar 2. Modul edukasi yang digunakan

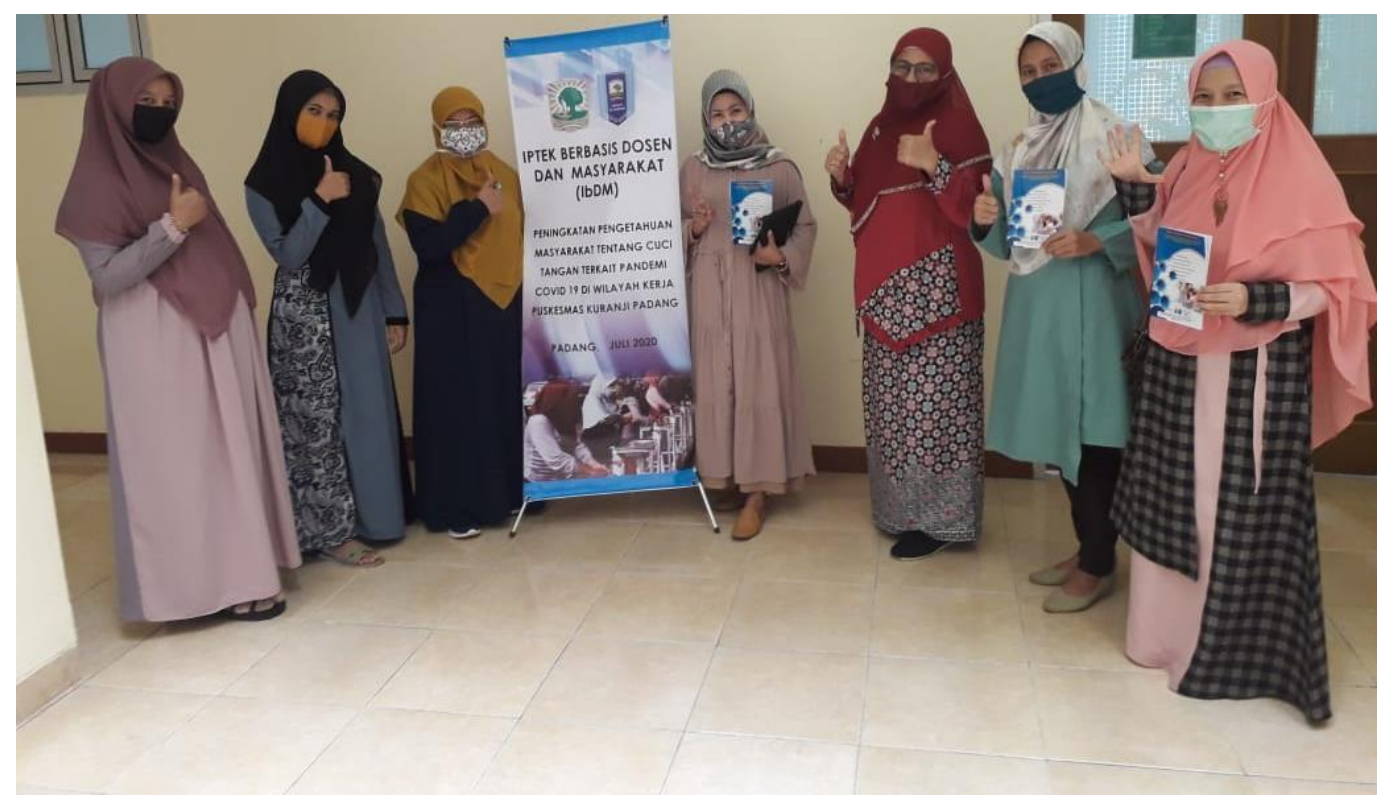

Gambar 3. Edukasi yang dilakukan kepada masyarakat

\section{KESIMPULAN}

Edukasi yang dilakukan kepada masyarakat secara online dari rumah ke rumah (door to door) sangat efektif dilakukan untuk meningkatkan pengetahuan mengenai pencegahan penularan Covid-19. Terlihat dari meningkatnya pemahaman setelah dilakukan post-test diakhir kegiatan edukasi. Kegiatan ini dapat dilakukan secara berkelanjutan dengan kerjasama dengan pihak Puskesmas Kuranji Padang dengan cara melakukan kontrol paska kegiatan kepada 
masyarakat. Kegiatan ini dapat membantu pemerintah dalam upaya memutus rantai penularan virus Covid-19. Kerjasama semua pihak merupakan keberhasilan kita bersama dalam menanggulangi wabah Covid-19.

\section{UCAPAN TERIMA KASIH}

Terima kasih kepada UP2M Fakultas Keperawatan Universitas Andalas sebagai penyandang dana sehingga kegiatan edukasi ini terlaksana dengan baik. Selanjutnya kepada Pihak Puskesmas Kuranji Padang yang telah memberikan ijin sehingga kegiatan ini terlaksana.

\section{DAFTAR PUSTAKA}

Direktorat Jenderal Pencegahan dan Pengendalian Penyakit. Pedoman Kesiapsiagaan Menghadapi Coronavirus Disease (COVID-19) Maret 2020. Jakarta: Kementerian Kesehatan Republik Indonesia; 2020.

Direktorat Jenderal Kefarmasian dan Alat Kesehatan. Standar Alat Pelindung Diri (APD) Dalam Manajemen Penanganan Covid-19. Jakarta: Kementerian Kesehatan Republik Indonesia; 2020.

Kementerian Kesehatan Republik Indonesia. 2020. Pedoman Pencegahan dan Pengendalian Coronavirus Disease.

Perhimpunan Dokter Paru Indonesia. (2020). Panduan Praktis Klinis: Pneumonia 2019-nCoV. PDPI: Jakarta.

UU Nomor 6 tahun 2018 tentang Kekarantinaan Kesehatan.

World Health Organization (WHO). 2020. Global surveillance for human infection with novelcoronavirus (2019-ncov). https://www.who.int/publications-detail/global-surveillance-forhuman-infection-with-novel-coronavirus-(2019-ncov). Diakses pada tanggal 20 Maret 2020. 